\title{
SISTEM PAKAR UNTUK MENDIAGNOSA PENYAKIT KUSTA MENGGUNAKAN METODE BACKWARD CHAINING (Studi Kasus : UPT Puskesmas Talango-Sumenep)
}

\author{
Siti Nuraisyah ${ }^{1}$, Indra Dharma Wijaya ${ }^{2}$, Mungki Astiningrum ${ }^{3}$ \\ ${ }^{1}$ Prodi Teknik Informatika, ${ }^{2,3}$ Jurusan Teknik Elektro, Politeknik Negeri Malang \\ 1. sitinuraisyah45@gmail.com, ${ }^{2}$ indra.dharma@gmail.com, ${ }^{3}$ mama.zahra@gmail.com
}

\begin{abstract}
Abstrak
Puskesmas Talango merupakan Unit Pelaksana Teknis Dinas Kabupaten atau kota (UPTD) yang berperan menyelenggarakan sebagian dari tugas teknis operasional dinas kesehatan kabupaten atau kota dan merupakan salah satu tempat pelayanan kesehatan masyarakat yang berada di Kabupaten Sumenep tepatnya di Kecamatan Talango. Puskesmas tersebut menjadi tumpuan kesehatan bagi masyarakat Talango dan sekitar karena Puskesmas Talango satu-satunya tempat berobat bagi masyarakat setempat.

Penyakit kusta adalah penyakit menular, menahun dan disebabkan oleh kuman kusta (Mycobacterium leprae) yang menyerang saraf tepi, kulit dan jaringan tubuh lainnya kecuali susunan saraf pusat.

Sistem pakar berasal dari istilah knowledge-based expert system. Istilah ini muncul karena untuk memecahkan masalah, sistem pakar menggunakan pengetahuan seorang pakar yang dimasukkan ke dalam komputer. Seorang yang bukan pakar menggunakan sistem pakar untuk meningkatkan kemampuan pemecahan masalah, sedangkan seorang pakar menggunakan sistem pakar untuk knowledge assistant.

Adapun tujuan yang akan dicapai adalah untuk membuat aplikasi sistem pakar yang berguna sebagai alat bantu untuk mendapatkan informasi dan dugaan awal dalam mendiagnosa penyakit kusta. Hasil dalam penelitian ini adalah sistem pakar untuk mendiagnosa penyakit kusta dengan menggunakan metode backward chaining ini dapat menyelesaikan masalah diagnosa penyakit kusta beserta memberikan solusi sementara kepada pasien. Backward chaining merupakan strategi pencarian yang arahnya kebalikan dari runut maju. Proses pencarian dimulai dari tujuan, yaitu kesimpulan yang menjadi solusi permasalahan yang dihadapi. Representasi pengetahuan yang digunakan adalah tabel keputusan, pohon pelacakan, kaidah produksi berbentuk IF-THEN.
\end{abstract}

Kata kunci : Sistem Pakar, Penyakit Kusta, Backward Chaining

\section{Pendahuluan}

Dunia kedokteran banyak menggunakan sistem pakar untuk membantu mendiagnosa suatu penyakit tertentu. Sistem pakar banyak membantu penggunanya dalam memperoleh suatu keputusan tentang penyakit serta memberikan solusi baik berupa himbauan atau saran pengobatan.

Dalam hal ini sistem pakar menawarkan hasil yang spesifik untuk dimanfaatkan karena sistem pakar berfungsi secara konsisten seperti seorang pakar manusia yang menawarkan nasihat kepada pemakai dan menemukan solusi terhadap berbagai permasalahan yang spesifik, termasuk juga dalam pemecahan masalah penyakit kusta. Tujuan sistem pakar ini sebenarnya bukan untuk menggantikan peran manusia tetapi untuk mensubsitusikan pengetahuan manusia ke dalam bentuk sistem sehingga dapat digunakan oleh banyak orang.
Dengan latar belakang masalah tersebut maka penulis tertarik untuk menyajikan judul "Sistem Pakar Untuk mendiagnosa Penyakit Kusta Menggunakan Metode Backward Chaining “.

Berdasarkan latar belakang permasalahan yang dibahas diatas penulis mencoba merumuskan masalah yaitu "Bagaimana aplikasi sistem pakar yang dirancang ini dapat menghasilkan sebuah informasi tentang penyakit kusta yang tepat dan akurat, Bagaimana sistem pakar dapat membantu dokter dalam mendiagnosa penyakit kusta, serta Bagaimana sistem pakar dapat menghasilkan informasi mengenai penyakit kusta dan solusi pengobatannya.

Untuk lebih terarahnya ruang lingkup penelitian ini, maka penulis mempersempit pembahasan permasalahan yaitu "Studi kasus dilakukan di UPT Puskesmas Talango, Input berupa 
tipe dan gejala-gejala penyakit kusta, Output yang dihasilkan adalah hasil diagnosa terhadap pasien yaitu tentang tipe penyakit kusta beserta solusi pengobatannya, Interaksi antara sistem dan user menggunakan pertanyaan beserta gambar jika diperlukan dari setiap gejala yang memerlukan jawaban "ya" atau "tidak" dari user.

Tujuan dari penelitian ini adalah aplikasi sistem pakar yang dirancang ini dapat menghasilkan sebuah informasi tentang penyakit kusta yang tepat dan akurat, sistem pakar dapat membantu dokter dalam mendiagnosa penyakit kusta, serta sistem pakar dapat menghasilkan informasi mengenai penyakit kusta dan solusi.

\section{Metode Penelitian}

Langkah-langkah yang ditempuh dalam menyelesaikan penelitian ini yaitu sebagai berikut:

2.1 Metode Pengumpulan Data

a. Studi literatur

Pada tahap ini penulis mengumpulkan infomasi melalui buku-buku, jurnal, bahan kuliah dan referensi dan mempelajari materi serta sumber-sumber data yang berhubungan dengan sistem pakar, metode backward chaining, tipe penyakit kusta, gejala-gejala penyakit kusta beserta solusinya.

b. Wawancara atau Observasi

Pada tahap ini pengumpulan data yang dilakukan dengan cara mengajukan pertanyaan-pertanyaan atau dialog secara langsung dengan pakar penyakit kusta di UPT Puskesmas Talango untuk mendapatkan informasi dan data-data yang diperlukan dalam penyusunan laporan skripsi.

c. Dokumentasi

Pada tahap ini pengumpulan data dilakukan dengan mengumpulkan dokumen-dokumen yang diperoleh dari data pasien kusta di UPT Puskesmas Talango.

\subsection{Perancangan sistem}

a. Use Case

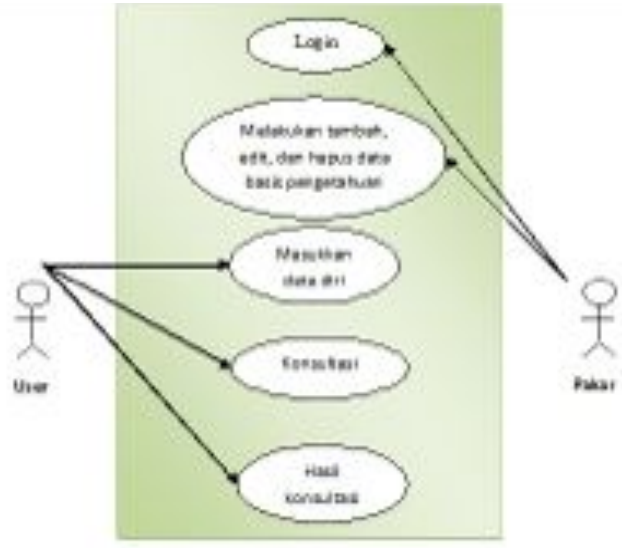

Gambar 2.1 Use Case

b. Work Break Down (WBS)

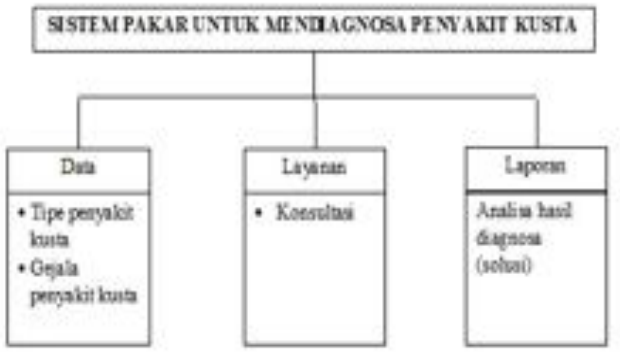

Gambar 2.2 WBS

c. Konteks Diagram

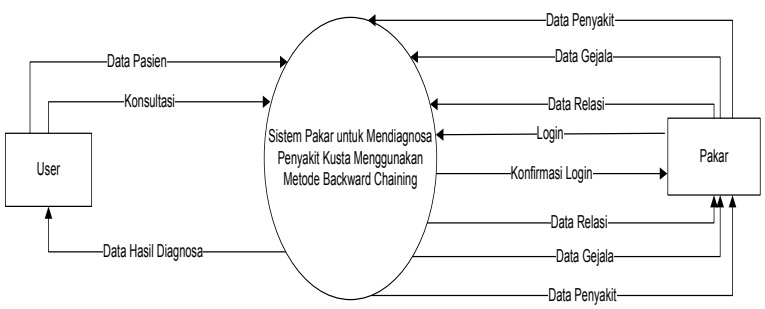

Gambar 2.3 Konteks Diagram

d. Flowchart

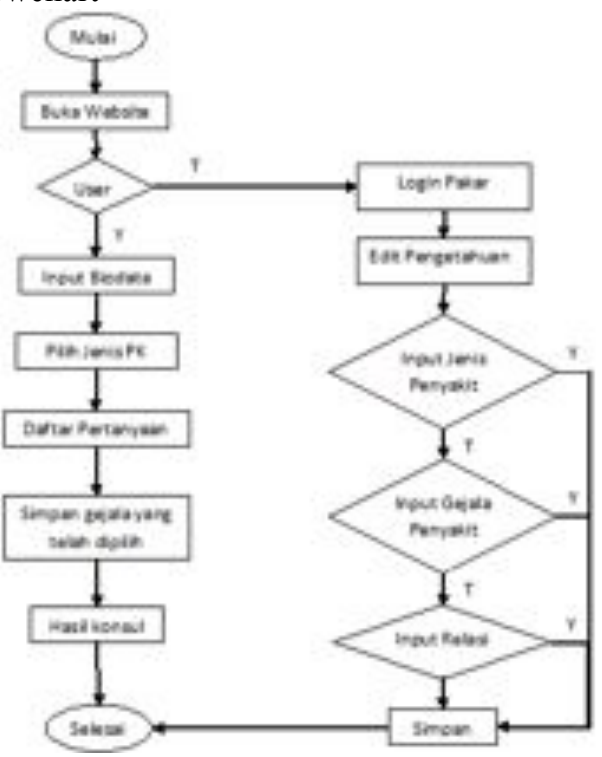


Gambar 2.4 Flowchart

\subsection{Penyusunan laporan}

Pada tahap ini dilakukan penulisan dokumentasi hasil analisis dari aplikasi sistem pakar dengan metode backward chaining untuk mendiagnosis penyakit kusta.

\section{Hasil}

3.1 Basis pengetahuan

Tabel 3.1 Tipe Penyakit Kusta (PK)

\begin{tabular}{|c|c|c|}
\hline Kode & Tipe PK & Solusi \\
\hline K001 & $\begin{array}{l}\text { Indeterminate } \\
\text { (I) }\end{array}$ & $\begin{array}{l}\text { Segera obati ke Puskesmas, } \\
\text { meskipun kebanyakan bila } \\
\text { dibiarkan tanpa pengobatan } \\
\text { kasus-kasus } \\
\text { Indeterminate kusta } \\
\text { kemungkinan akan sembuh } \\
\text { sendiri, tetapi hal ini tidak } \\
\text { menjadi jaminan. Pengobatan } \\
\text { pada stadium dini mudah dan } \\
\text { selalu berhasil. Setelah } \\
\text { pengobatan dihentikan, } \\
\text { selama empat tahun penderita } \\
\text { masih harus menjalani } \\
\text { pemeriksaan klinis dan } \\
\text { laboratorium bila mencurigai } \\
\text { terjadinya kekambuhan atau } \\
\text { relaps. }\end{array}$ \\
\hline K002 & Tuberkuloid (TT) & $\begin{array}{l}\text { Diobati selama 6-9 bulan, } \\
\text { setelah tanda aktif berakhir. } \\
\text { Tanda aktif seperti bercak- } \\
\text { bercak bertambah dalam } \\
\text { ukuran dan jumlah, } \\
\text { kemerahan terutama pada tepi } \\
\text { bercak, perubahan-perubahan } \\
\text { dari ketebalan bercak, yang } \\
\text { bisa lebih tipis atau lebih } \\
\text { tebal bisa dipastikan setelah } \\
\text { mengawasi penderita selama } \\
3 \text { - } 6 \text { bulan. Setelah } \\
\text { pengobatan dihentikan, } \\
\text { selama empat tahun penderita } \\
\text { masih harus menjalani } \\
\text { pemeriksaan klinis dan } \\
\text { laboratorium bila mencurigai } \\
\text { terjadinya kekambuhan atau } \\
\text { relaps. }\end{array}$ \\
\hline K003 & $\begin{array}{l}\text { Lepromatous } \\
\text { (LL) }\end{array}$ & $\begin{array}{l}\text { Penatalaksanaan atau } \\
\text { perawatan kasus kusta tipe ini } \\
\text { adalah sulit dan memakan } \\
\text { waktu yang lama sampai } \\
\text { bertahun-tahun lamanya atau } \\
\text { sampai seumur hidup. Untuk } \\
\text { kasus yang menular, diobati } \\
\text { secara teratur 12-18 bulan } \\
\text { sampai menjadi kasus yang } \\
\text { tidak menular. Setelah } \\
\text { pengobatan dihentikan, } \\
\text { selama empat tahun penderita } \\
\text { masih harus menjalani } \\
\text { pemeriksaan klinis dan } \\
\text { laboratorium bila mencurigai }\end{array}$ \\
\hline
\end{tabular}

\begin{tabular}{|c|c|c|}
\hline & & $\begin{array}{l}\text { terjadinya kekambuhan atau } \\
\text { relaps }\end{array}$ \\
\hline K004 & $\begin{array}{l}\text { Borderline } \\
\text { Tuberkuloid } \\
\text { (BT) }\end{array}$ & $\begin{array}{l}\text { Perhatikan kemungkinan } \\
\text { reaksi atau radang kerusakan } \\
\text { standar DDS selama }+6 \text { bulan } \\
\text { setelah semua tanda aktif } \\
\text { menghilang. Setelah } \\
\text { pengobatan dihentikan, } \\
\text { selama empat tahun penderita } \\
\text { masih harus menjalani } \\
\text { pemeriksaan klinis dan } \\
\text { laboratorium bila mencurigai } \\
\text { terjadinya kekambuhan atau } \\
\text { relaps. }\end{array}$ \\
\hline K005 & $\begin{array}{l}\text { Borderline } \\
\text { Borderline } \\
\text { (BB) }\end{array}$ & $\begin{array}{l}\text { Segera rujukan kasus ini ke } \\
\text { puskesmas, karena } \\
\text { kebanyakan dari penderita } \\
\text { kusta ini meskipun tidak } \\
\text { semuanya akan mengalami } \\
\text { reaksi-reaksi, } \\
\text { membutuhkan perawatan } \\
\text { medis dari tenaga ahli. } \\
\text { Setelah a pengobatan } \\
\text { dihentikan, selama empat } \\
\text { tahun penderita masih harus } \\
\text { menjalani pemeriksaan klinis } \\
\text { dan laboratorium bila } \\
\text { mencurigai terjadinya } \\
\text { kekambuhan atau relaps. }\end{array}$ \\
\hline K006 & $\begin{array}{l}\text { Borderline } \\
\text { Lepromatous } \\
\text { (BL) }\end{array}$ & $\begin{array}{l}\text { Kerusakan saraf sewaktu } \\
\text { reaksi tidak terjadi dengan } \\
\text { cepat. Dengan pengobatan } \\
\text { yang tepat seringkali dapat } \\
\text { sembuh kembali. Obati } \\
\text { selama 12-18 bulan setelah } \\
\text { semua tanda-tanda aktif } \\
\text { menghilang. Untuk kasus } \\
\text { yang menular, diobati secara } \\
\text { teratur }+6 \text { bulan sampai } \\
\text { menjadi kasus yang tidak } \\
\text { menular. Setelah pengobatan } \\
\text { dihentikan, selama empat } \\
\text { tahun penderita masih harus } \\
\text { menjalani pemeriksaan klinis } \\
\text { dan laboratorium bila } \\
\text { mencurigai terjadinya } \\
\text { kekambuhan atau relaps. }\end{array}$ \\
\hline
\end{tabular}

Tabel 3.2 Gejala-Gejala Penyakit Kusta

\begin{tabular}{|l|l|}
\hline $\begin{array}{c}\text { Kode } \\
\text { gejala }\end{array}$ & \multicolumn{1}{|c|}{ Nama Gejala } \\
\hline G001 & $\begin{array}{l}\text { Jumlah bercak yang menimbulkan hilang rasa } \\
\text { pada kulit 1-5 }\end{array}$ \\
\hline G002 & $\begin{array}{l}\text { Jumlah bercak yang menimbulkan hilang rasa } \\
\text { pada kulit }>5\end{array}$ \\
\hline G003 & Tepi bercak berbatas tegas \\
\hline G004 & Tepi bercak berbatas tidak tegas \\
\hline G005 & Permukaan bercak meninggi \\
\hline G006 & Bercak besar dan atau kecil \\
\hline G007 & Terdapat penyembuhan di tengah \\
\hline G008 & Terjadi perubahan warna pada bercak \\
\hline G009 & Batang saraf terserang \\
\hline G010 & Penyebaran bercak simetris \\
\hline G011 & Penyebaran bercak asimetris \\
\hline
\end{tabular}




\begin{tabular}{|l|l|}
\hline G012 & Terdapat nodul \\
\hline G013 & Permukaan bercak datar \\
\hline G014 & Terjadi penebalan kulit (infiltrat) \\
\hline G015 & Kelopak mata tidak dapat menutup mata \\
\hline G016 & Hilang rasa pada mata \\
\hline G017 & Kulit kering \\
\hline G018 & $\begin{array}{l}\text { Kelemahan otot disertai gejala mengecilnya } \\
\text { atau kerusakan otot }\end{array}$ \\
\hline G019 & Testis lebih kecil atau lunak \\
\hline G020 & Kulit retak \\
\hline G021 & Luka infeksi (ulkus) \\
\hline G022 & Bentuk bercak tidak teratur \\
\hline G023 & Cacat pada muka, tangan dan kaki \\
\hline G024 & Bercak meninggi dan berbentuk kubah \\
\hline G025 & Terdapat daerah normal di tengah bercak \\
\hline G026 & $\begin{array}{l}\text { Terdapat nodul pada kepala, lengan dan } \\
\text { tungkai }\end{array}$ \\
\hline G027 & $\begin{array}{l}\text { Terdapat plakat pada muka, lengan dan } \\
\text { tungkai }\end{array}$ \\
\hline G028 & $\begin{array}{l}\text { Makula berbatas tegas antara badan dan } \\
\text { bokong }\end{array}$ \\
\hline
\end{tabular}

Tabel 3.3 Tabel keputusan sistem pakar

\begin{tabular}{|l|l|l|l|l|l|l|}
\hline \multirow{2}{*}{$\begin{array}{l}\text { Kode } \\
\text { gejala }\end{array}$} & \multicolumn{7}{|c|}{ Ko01 } & K002 & K003 & K004 & K005 & K006 \\
\hline G001 & $*$ & $*$ & & $*$ & & \\
\hline G002 & & & $*$ & & $*$ & $*$ \\
\hline G003 & & $*$ & & $*$ & $*$ & \\
\hline G004 & $*$ & & & & & \\
\hline G005 & & $*$ & $*$ & & & \\
\hline G006 & & $*$ & & & $*$ & \\
\hline G007 & & $*$ & & $*$ & & \\
\hline G008 & & $*$ & & & & \\
\hline G009 & & $*$ & & & & \\
\hline G010 & & & & $*$ & & \\
\hline G011 & & $*$ & & & $*$ & $*$ \\
\hline G012 & & & $*$ & & & \\
\hline G013 & $*$ & $*$ & & $*$ & & \\
\hline G014 & & & $*$ & & & \\
\hline G015 & & & $*$ & & & \\
\hline G016 & & & $*$ & & & \\
\hline G017 & & & $*$ & & & \\
\hline G018 & & & $*$ & & & \\
\hline G019 & & & $*$ & & & \\
\hline G020 & & & $*$ & & & \\
\hline G021 & & & $*$ & & & \\
\hline G022 & & & & $*$ & & \\
\hline G023 & & & & $*$ & & \\
\hline G024 & & & & & $*$ & \\
\hline G025 & & & & & $*$ & \\
\hline G026 & & & & & & $*$ \\
\hline G027 & & & & & & $*$ \\
\hline G028 & & & & & & $*$ \\
\hline
\end{tabular}

\section{Pembahasan}

4.1. Tampilan User Interface

Berikut ini adalah contoh beberapa desain interface :

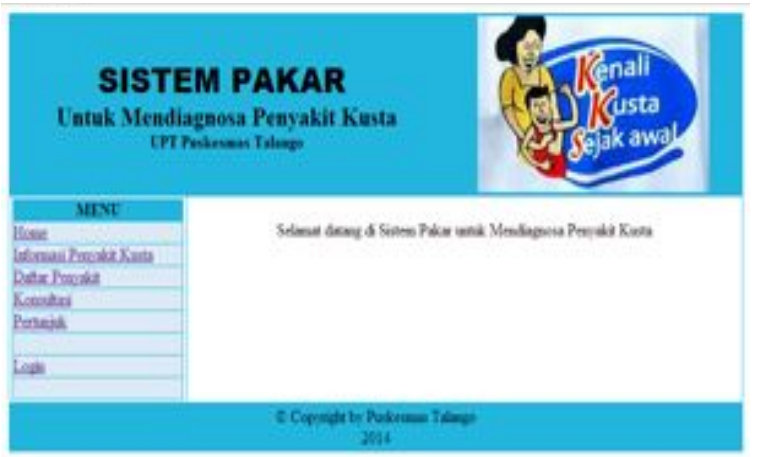

Gambar 4.1 Menu Utama

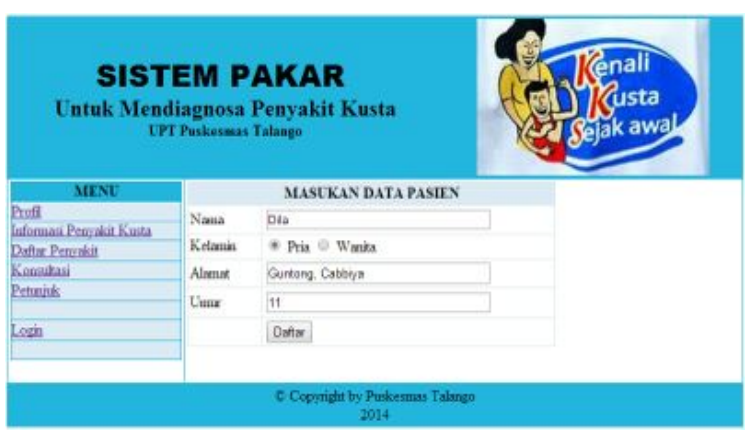

Gambar 4.2 Input Data Pasien

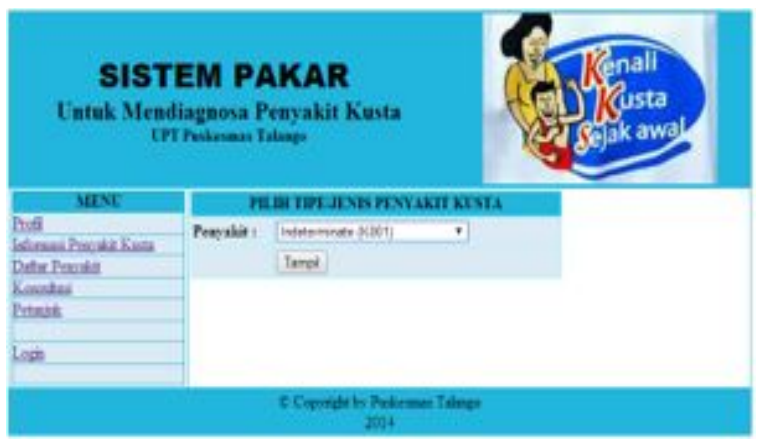

Gambar 4.3 Pilih Penyakit

JAWABLAH PERTANYAN BERIKUT :

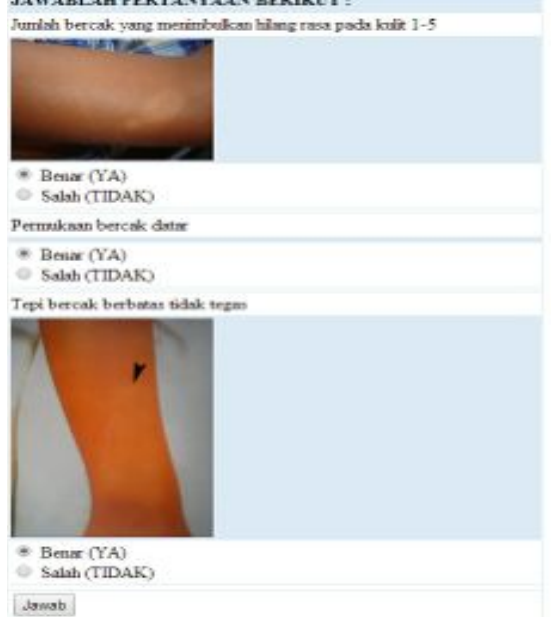

Gambar 4.4 Pilih Pertanyaan 


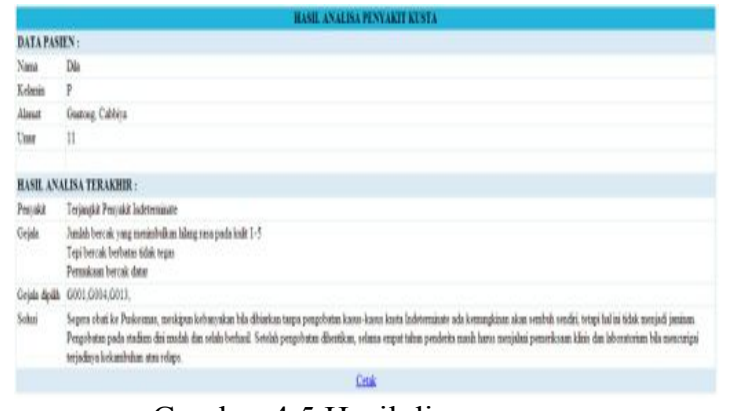

Gambar 4.5 Hasil diagnosa

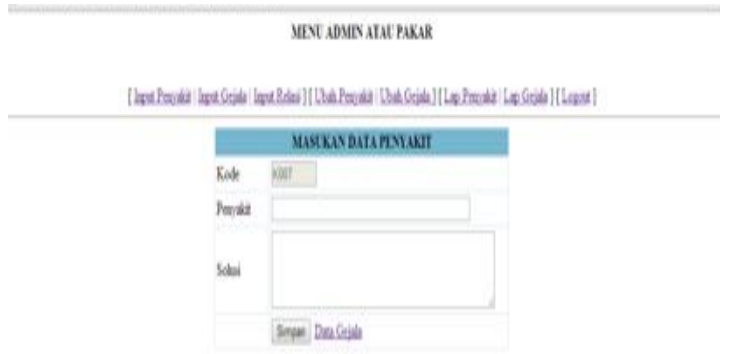

Gambar 4.6 Input Data Penyakit

$$
\text { SENT ADME ATAC PAKIR }
$$

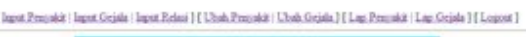

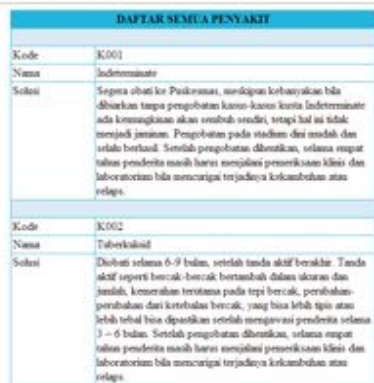

Gambar 4.7 Laporan Data Penyakit

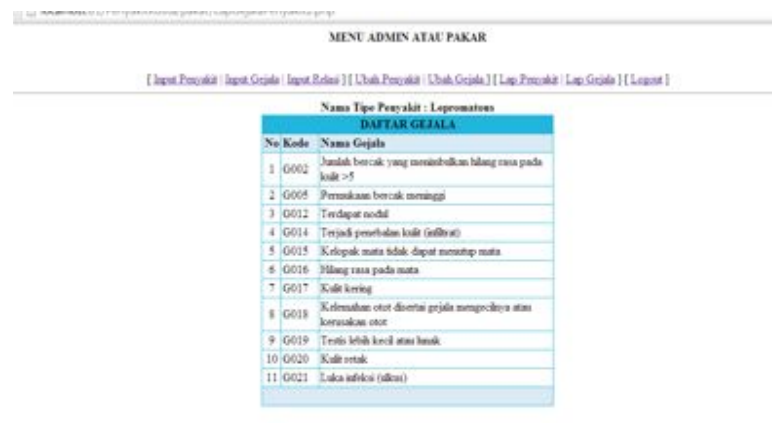

Gambar 4.8 Laporan Data Gejala

\subsection{Analisa Hasil}

Setelah dilakukan pengujian terhadap 20 sampel dari UPT Puskesmas Talango pada sistem pakar untuk mendiagnosa penyakit kusta. 16 diantaranya memperoleh hasil yang akurat dan 4 tidak memperoleh hasil yang akurat.

Kasus yang dinyatakan tidak akurat disebabkan karena kesalahan penulis dalam pembuatan program dan pengelompokan gejala, dimana penulis memberi patokan jika diatas $70 \%$ gejala terpenuhi maka pasien menderita tipe penyakit kusta. Sehingga sistem mengeluarkan nilai default output.

Nilai keakuratan sistem memiliki dua level yaitu level 0 jika diagnosa akhir sistem tidak sama dengan diagnosa pakar, dan level 1 jika diagnosa akhir sistem sama dengan diagnosa pakar. Kesesuaian hasil diagnosa penyakit pada sistem dengan diagnosa dari pakar dapat diketahui hasil diagnosa sesuai dengan sistem.

Tabel 4.1 Tabel Perbandingan

\begin{tabular}{|c|c|c|c|}
\hline Kasus & $\begin{array}{l}\text { Diagnosa } \\
\text { Pakar }\end{array}$ & Diagnosa Sistem & $\begin{array}{l}\text { Nilai } \\
\text { Keak } \\
\text { urata } \\
\text { n }\end{array}$ \\
\hline 1 & Lepromatous & Default & 0 \\
\hline 2 & $\begin{array}{l}\text { Borderline } \\
\text { Tuberkuloid }\end{array}$ & $\begin{array}{l}\text { Borderline } \\
\text { Tuberkuloid }\end{array}$ & 1 \\
\hline 3 & $\begin{array}{l}\text { Borderline } \\
\text { Borderline }\end{array}$ & $\begin{array}{l}\text { Borderline } \\
\text { Borderline }\end{array}$ & 1 \\
\hline 4 & $\begin{array}{l}\text { Borderline } \\
\text { Lepromatous }\end{array}$ & $\begin{array}{l}\text { Borderline } \\
\text { Lepromatous }\end{array}$ & 1 \\
\hline 5 & Lepromatous & Lepromatous & 1 \\
\hline 6 & $\begin{array}{l}\text { Borderline } \\
\text { Borderline }\end{array}$ & $\begin{array}{l}\text { Borderline } \\
\text { Borderline }\end{array}$ & 1 \\
\hline 7 & $\begin{array}{l}\text { Borderline } \\
\text { Borderline }\end{array}$ & Default & 0 \\
\hline 8 & Tuberkuloid & Tuberkuloid & 1 \\
\hline 9 & Lepromatous & Lepromatous & 1 \\
\hline 10 & $\begin{array}{l}\text { Borderline } \\
\text { Lepromatous }\end{array}$ & $\begin{array}{l}\text { Borderline } \\
\text { Lepromatous }\end{array}$ & 1 \\
\hline 11 & $\begin{array}{l}\text { Borderline } \\
\text { Borderline }\end{array}$ & $\begin{array}{l}\text { Borderline } \\
\text { Borderline }\end{array}$ & 1 \\
\hline 12 & Lepromatous & Lepromatous & 1 \\
\hline 13 & Tuberkuloid & Tuberkuloid & 1 \\
\hline 14 & $\begin{array}{l}\text { Borderline } \\
\text { Lepromatous }\end{array}$ & Default & 0 \\
\hline 15 & Lepromatous & Lepromatous & 1 \\
\hline 16 & $\begin{array}{l}\text { Borderline } \\
\text { Lepromatous }\end{array}$ & $\begin{array}{l}\text { Borderline } \\
\text { Lepromatous }\end{array}$ & 1 \\
\hline
\end{tabular}




\begin{tabular}{|l|l|l|l|}
\hline 17 & $\begin{array}{l}\text { Borderline } \\
\text { Borderline }\end{array}$ & $\begin{array}{l}\text { Borderline } \\
\text { Borderline }\end{array}$ & 1 \\
\hline 18 & Lepromatous & Lepromatous & 1 \\
\hline 19 & Tuberkuloid & Default & 0 \\
\hline 20 & Indeterminate & Indeterminate & 1 \\
\hline \multicolumn{3}{|c|}{ Jika dihitung probabilitasnya, akan }
\end{tabular}

diperoleh hasil sebagai berikut :

$\mathrm{P} 20($ akurat $)=16 / 20 \times 100 \%=80 \%$

$\mathrm{P} 20$ (akurat) $=4 / 20 \times 100 \%=20 \%$

Melihat nilai probabilitas yang mencapai $80 \%$, dengan metode backward chaining yang digunakan pada sistem ini menggunakan representasi pengetahuan berupa aturan produksi, menunjukkan bahwa sistem sudah berfungsi cukup baik.

\section{Penutup}

5.1 Kesimpulan

Berdasarkan uraian yang dikemukakan pada bab-bab sebelumnya, maka dapat diambil suatu kesimpulan dalam mencapai tujuan yang diinginkan. Adapun kesimpulan yang dapat diambil pada sistem pakar untuk mendiagnosa penyakit kusta ini adalah sebagai berikut:

3. Penelitian ini menghasilkan suatu program untuk mengidentifikasi penyakit kusta dengan menggunakan Pemrograman PHP dan MySQL server dengan menggunakan metode backward chaining.

4. Penelitian sistem pakar ini dilakukan dengan menggunakan 20 data sampel penderita kusta dari UPT Puskesmas Talango untuk menguji kesamaan diagnosa sistem dengan diagnosa pakar, yang memperoleh angka probabilitas kesamaan sebesar $80 \%$.

5. Dengan adanya program sistem pakar yang telah dibuat ini, dapat menjadi referensi dan dapat membantu dalam melakukan diagnosa terhadap gejala penyakit yang dirasakan oleh pasien.

6. Sistem pakar ini digunakan pada UPT Puskesmas Talango, sehingga para pengunjung atau pasien yang mengalami penyakit kusta, baik yang sedang menunggu dokter datang ataupun mengantri, setidaknya dapat menggunakan aplikasi ini dahulu sebelum berkonsultasi secara langsung dengan dokter.

7. Dengan adanya pembatasan hak akses yang diterapkan pada sistem, proses untuk pengolahan basis pengetahuan dan basis aturan hanya dapat dilakukan oleh pakar.

8. Sistem pakar ini bukan untuk menggantikan kedudukan seorang ahli maupun pakar, tetapi untuk memasyarakatkan pengetahuan dan pengalaman pakar-pakar yang ahli di bidangnya.

a. Saran

Adapun saran-saran yang dapat penulis sampaikan yang dapat memberikan manfaat dalam pelaksanaannya antara lain:

3. Program sistem pakar ini perlu dilakukan evaluasi secara rutin sehingga dapat dilihat apakah perlu adanya perbaikan atau penyempurnaan kembali.

4. Pengetahuan yang terdapat didalam basis pengetahuan sistem pakar ini terbatas pada jenis penyakit kusta pada manusia, penulis menyarankan agar pengembangan sistem pakar penyakit kusta selanjutnya tidak hanya terbatas pada jenis penyakit kusta saja.

\section{Daftar Pustaka:}

Adhisty, Sherly. 2011. "Sistem Pakar Pendektisian Penyakit Sistem Transportasi Tubuh Dengan Metode Backward Chaining”. Jurnal Sekolah Tinggi Manajemen Informatika dan Komputer AMIKOM. Yogyakarta.

Bryceson Anthony D.M., dan Pfaltzgraff Roy E. 1991. Leprosy. Singapore. Longman Singapore Publishers.

Cahyanti, Tri. 2010. Kenali Penyakit Kusta Lebih Dekat (http://puskesmaskutasatu.com/ diakses tanggal 10 Januari 2014)

Departemen Kesehatan RI, 2006. Buku Pedoman Nasional Pemberantasan Penyakit Kusta. Jakarta.

Guinto Ricardo S., et al. 2004. An Atlas Of Leprosy : Atlas Kusta. Diterjemahkan oleh Direktorat Jenderal Pemberantasan Penyakit Menular dan Penyehatan Lingkungan. Sasakawa Memorial Health Foundation.

Kosasih A., Wisnu I.M., Sjamsoe-Daili E.S., Menaldi S.L. 2010. Ilmu Penyakit Kulit dan Kelamin. Jakarta. Fakultas Kedokteran Universitas Indonesia.

Kusumadewi, Sri. 2003. Artificial Intelligence (Teknis dan Aplikasinya). Yogyakarta: Graha Ilmu.

Nigroho, Bunafit. 2008. Membuat Aplikasi Sistem Pakar dengan PHP dan Editor Dremaweaver. Yogyakarta: Gava Media.

Sutojo, T., dkk. 2011. Kecerdasan Buatan. Yogyakarta: Penerbit ANDI.

Yunanto, Wawan. 2003-2007. Algoritma Backward Chaining pada Rule-Based Expert System, Komunutas eLearning IlmuKomputer.com 
